\title{
THE EQUIVALENT OF THE JAPANESE VERBS SONAERU, SASHIAGERU, AND SAZUKERU INTO INDONESIAN
}

\author{
Made Ratna Dian Aryani ${ }^{1}$, Renny Anggraeny ${ }^{2}$ \\ 1,2 Japan Literature, Faculty of Sciences, Universitas Udayana, Jimbaran, Indonesia
}

Corresponding Author: MadeRatna Dian Aryani,E-mail: dian aryani@unud.ac.id

\begin{tabular}{|c|c|}
\hline ARTICLE INFO & \multirow{11}{*}{$\begin{array}{l}\text { This research focuses on the verb equivalent of 'giving' Japanese into Indonesian. } \\
\text { Japanese and Indonesian have different expressions of the 'giving' verb, both } \\
\text { syntactically and pragmatically. The method used in this study is a qualitative } \\
\text { descriptive method. In this study, the theory used is semantic theory from Chaer } \\
\text { which states lexical meaning and grammatical meaning. The pragmatic theory } \\
\text { used in this study is the contextual theory from Pateda. The data source of this } \\
\text { study uses data from the Japanese corpus, namely } \\
\text { www.kotonoha.gr.jp/shonagon/.The results of this study indicate that syntactically } \\
\text { the verbs of sonaeru, sashiageru and sazukeru each have a different structure in } \\
\text { Japanese. This is related to the emergence of function markers in arguments in } \\
\text { Japanese sentence structures. And semantically, the emergence of the function of } \\
\text { the marker affects the meaning and use of the vocabulary. }\end{array}$} \\
\hline Received: 19-8-2021 & \\
\hline Accepted: 15-10-2021 & \\
\hline Published: 30-10-2021 & \\
\hline & \\
\hline Issue & \\
\hline DOI: & \\
\hline $\mathrm{htt}$ & \\
\hline & \\
\hline KEYWORDS & \\
\hline $\begin{array}{l}\text { Linguistics Landscape, } \\
\text { Culinary Sign, Melting Pot }\end{array}$ & \\
\hline
\end{tabular}

\section{INTRODUCTION}

Japanese society is very concerned about politeness in speech. This also becomes one of the characteristics of Japanese, hereinafter abbreviated (BJ), namely the level of politeness in language. The expression of politeness in Japanese can be expressed grammatically and lexically. Indonesian, hereinafter abbreviated (BI), which is good and right, can be interpreted as the use of various languages that are in harmony with the target, in addition to following the correct language rules. In certain conditions, namely the formal situation of the correct use of Indonesian language is a priority. This usage is of ten called using standard language. Indonesian does not have a level of politeness in language, speech situation or conversation context that can affect the meaning of each vocabulary.

Lehmann (in Sudaryanto, 1986:6) states that "every central part of a language is a verb". That is, it is verbal who first determines the existence of various structures of constructions in the language concerned and their changes. The main function of a verb is as a predicate or as a core predicate in a sentence. Furthermore, Givon (2001:64-73) observes that the characteristics of a verb can be observed through three characteristics, namely semantic, morphological, and syntactic.

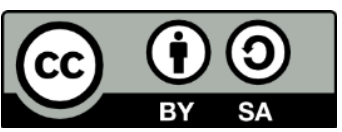

276

This work is licensed under Creative Commons Attribution-ShareAlike 4.0 Internasional. Copyright @ 2021, Made Ratna Dian Aryani, Renny Anggraeny 
Japanese is a language that is rich in structure. The diversity of these structures makes Japanese one of the languages that is difficult for foreign students to learn who havea typologically different mother tongue than Japanese, such as Indonesian. More over, the language learned is influenced by the culture of the speaker. The Japanese structure that is associated with the verb や る yaru 'give' / もらう morau 'take' or やりもらい yarimorai 'give-take 'and other variants or commonly called 授受 動詞 jujudoushi and the use of this verb in everyday speech can be called 授受表現 表現jujuhyougen.

The 'give' verb BI has eight meanings namely (1) giving (sharing, conveying) something; (2) providing (doing) something for; (3) allow, permit; (4) cause (make) suffer (hit); (5) making so that; (6) affix (lay down, wear); (7) say (deliver); and (8) flying, sending (punches, kicks). Whereas the phrase yarimorai has seven terms as the main verb 'give' in BJ, namely ageru, sashiageru, yaru, kudasaru, kureru, sonaeru, and sazukeru. This diversity and the similarity of some of the meanings contained in the expression yarimorai will certainly make mistakes in communication, especially for BJ learners.

Related to the above, then the theory that will be used in this research is uses the theory of The Lexical Meaning of Chaer (2009:60) states that lexical food is an adjective form derived from noun lexicons. The unit of lexicon is lexeme, which is a unit of meaningful form of language. If the lexicon is equated with vocabulary or vocabulary, then a lexicon which means a lexicon, is a lexicon, and is a word. Thus, lexical meaning can be interpreted as meaning which is lexicon, lexemic, and word-like. Itcan also be said that lexical meaning is the meaning that is in accordance with the referent, the meaning that is in accordance with the results of our lives. The Grammatical Meaning of Chaer (2009: 62) states "Grammatical meaning is the meaning that is present as a result of grammatical processes such as the affixation process, the reduplication process, and the composition process." sister contains the meaning 'can' and in the sentence When the beam is pulled, the father is lifted up giving birth to the meaning of 'accidentally'.

The theory of contextual meaning according to Pateda (2001: 116) states that contextual meaning or situational meaning arises as a result of the relationship between speech and context. 
The context of the similarity of languages influences the overall meaning. The context in question is, among others.

1. The context of the person is the context relating to the sex, position of the speaker, the age of the listener or speaker, the social or economic background of the speaker or listener. In the context of the person, a person is forced to use words whose meaning is understood by the interlocutor according to age, gender, socioeconomic background and educational background.

2. Context of the situation, for example a dispute situation, safe situation (conducive) or dangerous. Someone will look for words whose meaning is related to the situation for example using words whose meanings are sad, sorry, saying and so forth.

3. Context of purpose, for example asking or expecting something to ask for purpose, then someone will look for words that mean asking.

4. The formal context of whether or not a conversation, forcing someone to look for words that match the formal or not the conversation.

5. The context of the mood of the speaker or listener, forcing someone to look for words whose meaning expresses the mood of the speaker or listener, for example fear, joy or annoyance.

6. Time context, for example day or night. This can be seen from the meaning of the words someone uses.

7. Context of place, for example in the cinema or in the market, place context greatly influences the word used.

8. Context object is the thing that is the focus of the conversation. For example, the focus of the speaker is on economics, then people will look for words related to economics.

9. Context of speaker or listening equipment on speaker or listener. For example, a person who is not normal in his speech when pronouncing a word but the word cannot be pronounced well, so that the person who hears cannot understand what is in the sentence and causes misunderstanding.

10. The linguistic context is to meet or not the linguistic method between the speaker and the interlocutor. For example, in writing, writing the things that are considered are 
punctuation and diction, while in spoken language, the sound pressure, the short length and the vibration of the voice that indicates certain emotions.

11. Language Contexts The language used. This indicates that a word or utterance symbol will not have meaning if apart from the context of the sentence.

Problems as above, it is important to study further so that the case can be described in the structure of BJ. In this regard, the use of the marker in the BJ sentence structure does only have a one meaning, but can also express other meanings. Regarding the mother tongue we use (Indonesian or regional language), it is necessary to have a deeper study regarding the use of these verbs of sonaeru, sashiageru and sazukeru or another vocabulary. Vocabulary understanding is very necessary. We as foreign language learners, we should be obliged to know the use of these vocabulary, so as to minimize language interference and communication misunderstandings.

\section{LITERATURE REVIEW}

This research is related to the research issues in Japanese Dative Case by Miyagawa \& Tsujioka (2004), Shibatani (2012), Sugai (2000), Aryani (2016), and Ary ani (2019). There are several things discussed, among others. (1) Dative verbs are semantically based. (2) Use of particles for data verbs. Aryani's research examines dative verbs in Japanese in terms of structure and meaning. This research shows that dative verbs are verbs whose presence has the potential to give rise to indirect objects (IO). The results of this study are (1) verbs that allow the emergence of indirect objects (IO) in Japanese are transitive verbs with particle $n i$, and (2) those verbs are ageru 'give', oshieru 'teaching', kureru 'give', and kau 'buy'. Semantically these verbs are the keizoku doushi 'continuous verbs'.

\section{METHODOLOGY}

This research uses descriptive qualitative analysis method. The method is used to retrieve data taken from Japanese data corpus. Data source for Japanese-language corpus is www.kotonoha.gr.jp/shonagon/. The use of the language used by the speakers does not consider right and wrong, in line with what Sudaryanto (2015: 62). In addition, in the research data collection process, it must be kept in mind that the data taken is grammatical and acceptable data, 
both semantically and pragmatically. Method to scrutinize the use of words and adverbs dative aids in Japanese sentence in the source data. The equivalent method used in this study is the referential equivalent method (the determinant is the fact indicated by the language), and the translational equivalent method (using another language) whose determinant is another langue, in this case Indonesian.

The element sorting technique can be used to determine the nature and character of different languages. Japanese (BJ) has a different system with Indonesian (BI). For example, Japanese has a marking system, changing verbs but in Indonesian it doesn't. By using the element sorting method and assisted by the researcher's understanding of the rules that apply in Japanese, the language elements that exist in different languages can be identified. This informal method is realized by revealing the results of research through describing the results of the study in words or sentences to form a discourse in the form of research articles.

\section{RESULTS AND DISCUSSION}

In this section, an analysis of the verbs sonaeru, sashiageru and sazukeru will be presented.

A. The 供える sonaeru verb has the following lexical meaning: to serve, to complete, to give, to install, offer, to provide. Pay attention to the data below.

Data 1):

本堂前では、雪が舞う中で本堂などに 供える 鏡餅の餅つきが行われた。 Hondō maede wa, yukidoesn't want naka de hondōnado ni sonaeru kagamimochino mochi-tsuki no okonawa reta.

'In front of the main hall, Kamakura rice cakes and others are made for serving in the main hall, when it snows. "

(Yahoo !, 2008)

In the data sentence (1) use the verb 供える sonaeru 'presentation' of the positive verb in the active BJ sentence pattern. Sentence data (1) above, sonaeru verb 'presentation' is a transitive verb in the form of the dictionary sonae $\{\boldsymbol{r} \boldsymbol{u}\}$ 'provides', from the verb sonae $\{\boldsymbol{r} \boldsymbol{u}\}$ 'provides' + noun, so 
it shows the verb that explains the noun. The meaning contained in the sentence data (1) states 'presentation'. Sentence structure data (1) contains Subject - Predicate. So, in the data sentence (1) it does not bring up three mandatory arguments, and negative particles which state the indirect object. Verb sonaeru 'penyajian' in Indonesian is paired like this to facilitate understanding in the meaning of Indonesian and adapted to grammatical meaning.

Data 2):

お供えとして神棚などに多く供えるからこのように言われているのだそうです。 Osonae to shite us nado ni ōku sonaeru kara kono yō ni iwa rete is also a smudge sōdesu.

"It is said that this is because many offer on the god shelf (temple) as offerings.

(Yahoo !, 2008)

In the data sentence (2) using the verb 供える sonaeru 'presents' of the positive verb in the active BJ sentence pattern. Sentence data (2) above, the verb sonaeru 'offering' is a transitive verb in the dictionary form sonae $\{\boldsymbol{r} \boldsymbol{u}\}$ 'offering', from the verb in the form sonae $\{\boldsymbol{r u}\}$ 'offering' + から which shows cause and effect. 2) states 'offer' something for God. The sentence data structure (2) contains clause 1 から、 clause 2 with the predicate です which shows noun. So, in the data sentence (2) does not bring up three mandatory arguments, and negative particles which state the indirect object. The verb sonaeru 'mempersembahkan' in Indonesian is paired like this to facilitate understanding in the meaning of the Indonesian language and adapted to grammatical meaning. Data 3):

お仏壇にご飯（円筒系に型を取りますを供えるんですが、家では「おぼくさま」って呼 んでいるんです。

Obuttan ni gohan (entō-keini word o torimasu) o sonaerundesuga, ie de wa "o boku-sama" tte yonde iru ndesu.

'At the altar, prepare a bowl of rice (in cylindrical form, but at home, we call it" Osasama ").'

(Yahoo!, 2005) 
In the data sentence (3) use the verb 供える sonaeru 'prepare / provide' of the positive verb in the active BJ sentence pattern. Sentence data (3) above, the verb sonaeru 'prepare / provide' is a transitive verb in the dictionary form sonae $\{\boldsymbol{r u}\}$ 'prepare/provide', from the verb form dictionary sonae $\{\boldsymbol{r} \boldsymbol{u}\}$ 'prepare / provide' + んです, so that it shows the sentence structure which requires further information / information. The meaning contained in the data sentence (3) states 'prepare / provide'. The data sentence structure (3) contains clause 1 んですが、 clause 2. So, in the data sentence (3) it does not bring up three mandatory arguments, and negative particles that declare an indirect object. The verb sonaeru 'menyiapkan/menyediakan in the Indonesian language paired like this to facilitate understanding in the meaning of the Indonesian language and adapted to the grammatical meaning.

B. The さしあげる sashiageru verb has the following lexical meaning: to give. Pay attention to the data below.

Data 4):

一頭まるまるを、お客さんにさしあげるためです。それが最高のもてなしとなっていま す。

Ichi-tō marumaru o, okyakusan ni sashiageru tamedesu. It's late afternoon saiko no motenashi to natte imasu.

'This is for the purpose of offering the entire circle to the customer. That is the best treat. '

(Rekishi, 1981)

In the data sentence (4) use the verbさしあげる sashiageru 'offer / give' of the positive verb in the active BJ sentence pattern. Sentence data (4) above, the sashiageru verb 'offer / give' is a transitive verb in the dictionary form sashiage $\{\boldsymbol{r u}\}$ 'offer / give', from the verb form of the dictionary sashiage $\{\boldsymbol{r} \boldsymbol{u}\}$ 'offer/give' +ため, so that it shows the pattern of the form for . Meaning contained in the data sentence (4) states 'offer / give'. The sentence data structure (4) contains the お客さんに okyakusan ni 'to the customer/ guest' as the recipient's argument functions 
grammatically as an indirect object,一頭まるまを Ichi-tō marumaru o 'lingkaran /a circle’ as an argument that the recipient's grammatical function is an indirect object. Because the data in sentence (4) is a direct sentence, so the speaker or giver grammatical function subject is obscured. That sentence is accepted in Japanese.

Thus, in sentence data (4) raises three arguments, and negative particles which state the indirect object as recipients. The sashiageru 'beri/menawarkan' in Indonesian is paired like this to facilitate understanding in the meaning of the Indonesian language and adapted to the grammatical meaning.

Data 5):

「一回のレッスンで一○ドルさしあげるわ」そう言うと、ミセス・ドリスコルはにっこ り笑みを浮かべた。

'Ikkai no ressun de ichi rei-doru sashiageru wa 'sō iu to, misesu dorisukoru wa nikkori emi o ukabeta.

‘" I'll pay \$ 10 for one lesson, "said Mrs. Doriscor, smile. '

(Bungaku, 2004)

In the data sentence (5) use the verbさしあげる sashiageru 'pay / give' from the positive verb in the active sentence pattern BJ. Sentence data (5) above, the sashiageru verb 'pay / give' is a transitive verb in the dictionary form sashiage $\{\boldsymbol{r u}\}$ 'offer / give', from the verb form of the dictionary sashiage $\{\boldsymbol{r u}\}$ 'pay / give' +そう言うと, which states direct sentence. The meaning contained in the data sentence (5) states 'pay / give'. The sentence data structure (5) contains ミセ ス・ドリスコは Mrs. Doriscor 'Ny. Doriscor 'is the grantor's argument that functions grammatically on the subject, the recipient's argument that functions grammatically does not occur indirectly in the data sentence (5). However, the data sentence (5) is still acceptable both in meaning and structure in Japanese. Because the sentence is a direct sentence in Japanese. In addition, the sentence data (5) containing 一 $\bigcirc$ ドル Ichi rei '10 dollars' is an argument for something that functions as a direct object grammatical object, and there is a lapse of the auxiliary 
word を o which is common in a direct conversation, as the recipient said to help does not appear because the context of the data sentence (5) is a dialog sentence or conversation sentence.

Thus, in the data sentence (5) there are three arguments, and negative particles that state the indirect object as recipients. The verb sashiageru 'membayar/beri' in Indonesian is paired like this to facilitate understanding in the meaning of Indonesian and adapted to grammatical meaning.

Data 6):

ブラモン氏では、娘をこの方にさしあげるということだ。これが謎の全容だ。

Bura Mon-shi de wa, musume o konokata ni sashiageru to iu kotoda. Kore nazo no zen'yōda.

Mr. Bramon-So, I mean that I gave my daughter to this person. This is the whole picture of the mystery.'

(Bungaku, 1998)

In the data sentence (6) using the verb さしあげる sashiageru 'gives' of the positive verb in the active BJ sentence pattern. Sentence data (6) above, the verb sashiageru 'gives' is a transitive verb in the dictionary form sashiage $\{\boldsymbol{r u}\}$ 'gives', from the verb sashiage dictionary form $\{\boldsymbol{r u}\}$ ' gives'+ということだ、 so that it shows the sentence sentence pattern. The meaning contained in the data sentence (6) states 'offer/give'. The sentence structure of data (6) raises three mandatory arguments, namely ブラモン氏 Bura Mon-shi de wa 'Mr. Brumon' as the grantor's argument functions the subject's grammatical function, この方に kono the word ni 'to this person' as the recipient's argument (raises negative particles) function as an indirect object, and 娘を mи sumeo 'my daughter' as an argument something given functions as a direct object. The sashiageru verb 'memberi' in Indonesian is paired like this to facilitate understanding in the meaning of Indonesian and adapted to grammatical meaning. 
In Indonesian, the words "give" and "receive" are only known, but in Japanese the word "give" is divided into two, namely yaitu あげる ageru andくれる kureru which have the same meaning "give" but have different functions.

\begin{tabular}{llll}
\hline \multicolumn{1}{c}{ Position } & \multicolumn{1}{c}{ Elder } & \multicolumn{1}{c}{ Same Grade } & \multicolumn{1}{c}{ Younger } \\
\hline $\begin{array}{l}\text { Give } \\
\text { (To others) }\end{array}$ & さしあがえる & あげる & やる・あげる \\
$\begin{array}{l}\text { Give } \\
\text { (To the speaker) }\end{array}$ & くださる & くれる & $<れ る$ \\
\hline
\end{tabular}

a)さしあげる sashiageru'give'

$\rightarrow$ give / give something to people who are higher up.

The sentence structure used is

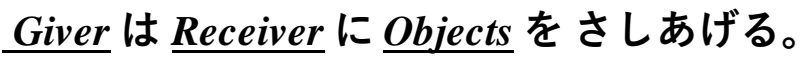

Example:

一昨日私は社長に日本のお土産をさしげました。

Kinou watashi wa shachouni nihon no omiyage o sashiagemashita.

'Yesterday I gave a present from Japan to the President Director.'

- 私はウダヤ学大学の先生に記念品をしあげました。

Watashi wa Udayana daigakuno sensei ni kinen hin o sashiagemashita.

'I give a memento to Udayana University lecturer.'

This phrase is not used for people whose age is older, but their close relationship with speakers such as parents, grandparents, sisters, or seniors at school. Used for people who are truly higher than speakers such as head of offices, high-ranking officials, people who are truly respected such as figures, guests, clients in the business world, or people who are just known by the speaker.

b)あげる ageru 'give / give'

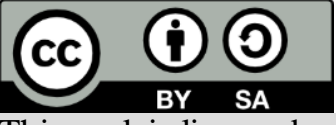


$\rightarrow$ give / give something to people of equal status.

The sentence structure used is

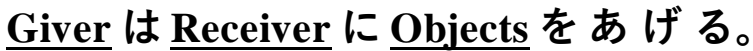

あげる agerudused when the speaker / subject gives something / does good to others

Example :

一私はあなたにお菓子をあげる。 watashi wa anata ni okashio ageru

'I gave you candy.'

一私は日本語を教えてあげます。 watashi wa nihongo o oshiete agemasu 'I will teach Japanese.'

c)くれる kureru' give / give'

$\rightarrow$ give / give something to people of equal status.

The sentence structure used is

\section{Giver は $\underline{\text { Receiver (me /my client / P1) }}$ に Objects をあげる。}

This word has the same meaning as あげる 'ageru' but is used in a different situation from あげ る which is when the speaker is given by someone else, and just like あげる,くれる can also be affixed in verb tenses. Example:

一 美子さんは私 にプゼントをくれました。 Miko-san wa watashi ni purezento o kuremashita 'Miko-san gave me a present.'

一先生 は日本語を僕に教えてくれた。 sensei wa nihongo o boku ni oshiete kureta 'The teacher taught me Japanese.'

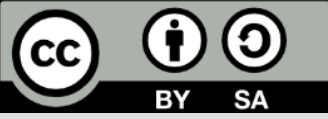


C. The 授ける sazukeru verb has the following lexical meaning: for appreciation, giving, for teaching. Pay attention to the analysis below.

Data 7):

つまり、師匠が 弟子に、その道の奥義や秘伝をすべて教えるのです。そし「目録」を 授けるのです。

Tsumari, shishō ga deshi ni, sonomichi no ìgi ya hiden o subete oshieru nodesu. Soshite, 'mokuroku' o sazukeru no desu.

'In other words, the teacher teaches his students all the mysteries and secrets of the path. And, you will receive inventory.'

(Yahoo!, 2005)

In the data sentence (7) using the 授ける sazukeru 'teach' of the verb tansitive in BJ's direct active sentence pattern. Sentence data (7) above, sazukeru verb 'teaches' is a transitive verb in the dictionary form sazuke $\{\boldsymbol{r u}\}$ 'teaches', from the verb form sazuke $\{\boldsymbol{r u}\}$ 'teaches', + particle no which shows noun substitute その道の 奥義秘伝を sonomichi no ogi ya hiden o 'the secret of the road and all the mysteries'. The meaning contained in the sentence data (7) states 'teach'. The sentence data structure (7) containing 師匠 が shishō ga 'teacher' is an argument that grammatical functions as a subject, 弟子に deshi $n i$ 'to students' is a recipient's argument that functions grammatically as a non-continuous object, and 目録を mokuroku o 'inventory' is an argument something which is given which functions grammatically as a direct object.

Thus, it does not bring up the three arguments in the structure of the data sentence (7), and the negative particle which states the indirect object. The sazukeru verb 'mengajar' in Indonesian is paired like this to facilitate understanding in the meaning of the Indonesian language and adapted to the grammatical meaning.

Data 8)

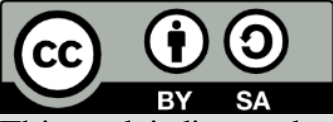


これらはすべていわば実験なのである.すべての徵収は王の戦争遂行を授けるため の, 社会の一時的な援助金とみなされる.

Korera wa subete iwaba jikken'na nodearu. Subete no chōshū wa ō no sensō suikō o sazukeru tame no, shakai no ichiji-tekina enjo-kin to minasa reru.

This is all, one might say, experiment. All levies were considered as temporary social assistance for the execution of the king's war.'

(Rekishi, 2004)

In the data sentence (8) using the 授ける sazukeru 'gives' of a positive verb in the active direct sentence pattern BJ. Sentence data (8) above, sazukeru verb 'social assistance' is a transitive verb in the dictionary form sazuke $\{\boldsymbol{r u}\}$ 'giving', from the verb sazuke $\{\boldsymbol{r u}\}$ 'giving', although it is not explicitly written that sazukeru means to give, but based on the context of the sentence the execution of the war is a gift / assistance. The meaning contained in the sentence data (8) states 'give'. The sentence data structure (8) contains これらは karaera wa 'they' 戦争遂行を sensō suikō o 'social assistance / war victims assistance'. So, it does not bring up the three arguments in the structure of the data sentence (8), and the negative particle which states the indirect object. The sazukeru verb 'memberi' in Indonesian is paired like this to facilitate understanding in the meaning of Indonesian and adapted to grammatical meaning.

Data 9)

ミカエルとその使いによって地に落とされる。その地で一匹の獣に出会い、自らの権威 を授けると、その獣は神を污す言葉を口にし始めたという。

Mikaeru to sono tsukai ni yotte ji ni otosa reru. Sono ji de itsupiki no kemono ni deai, mizukara no ken'i o sazukeru to, sono kemono wa we o yogosu kotoba o kuchi ni shi hajimeta to iu.

'It was dropped to the ground by Michael and his angels. When he met a beast on the land and gave his authority, he said that the beast began to spit out words that defiled the name of God. '

(Rekishi, 2001)

In the data sentence (9) using the verb 授ける sazukeru 'gives' of the positive verb in the direct active sentence pattern BJ. Sentence data (9) above, sazukeru verb 'gives' is a transitive verb 
in the dictionary form sazuke $\{\boldsymbol{r} \boldsymbol{u}\}$ 'gives', from the verb sazuke $\{\boldsymbol{r} \boldsymbol{u}\}$ 'gives' + a presupposition form to indicate that the event will definitely occur. The meaning contained in the data sentence (9) states 'give'. The sentence data structure (9) contains ミカエルとその 使 mikaeru to sono tsukai 'Michael and his angels' shows the subject's argument, 一匹の獣に ippiki no kimono $n i$ ' an animal 'as an indirect object argument, and 権威を ken'i 'authority' as a direct object argument. Thus, the data sentence (9) gives rise to three arguments, and negative particles representing an indirect object. The sazukeru verb 'memberi' in Indonesian is paired like this to facilitate understanding in the meaning of Indonesian and adapted to grammatical meaning.

\section{CONCLUSION}

Based on the analysis of the 9 sentence data above, that the equivalent of the Japanese verb sonaeru, sashiageru, and sazukeru in the Indonesian sentence structure shows that the three verbs are lexically, namely sonaeru, sashiageru, and sazukeru are meaningful giving. It shows a clear difference that:

A. The 供える sonaeru verb is a transitive verb that shows the meaning of giving from lower status to higher status. Commonly used from humans to gods or gods. In the Big Indonesian Dictionary (https://kbbi.kemendikbud.go.id/kosakata) presents: /mem.per.sem.bah.kan/ V presents; give as offerings. In addition, the sonaeru verb has a broader lexical meaning that can express offer, present, provide, prepare, present from someone who is positioned down to the boss. This is consistent with the data sentence (1-3). Structurally the verb 供える sonaeru does not raise three arguments, namely the giver は, the recipient of something and something given を o. But still acceptable in Japanese grammar. Semantically and pragmatic use of diction and politeness in Japanese that the verb meaning 供える sonaeru 'presents' to make it easier for 
students to understand the use of the verb 供える sonaeru 'offer' according to the context of the sentence.

B. The さしあげる sashiageru verb is a transitive verb that shows the meaning of giving from lower status to higher status. Commonly used from humans to gods or gods. In the Big Indonesian Dictionary (https://kbbi.kemendikbud.go.id/kosakata) presents:/mem.be.ri.kan/ V presents; give to someone. In Indonesian it can be interpreted as offering. This is consistent with the data sentence (4-6). Structurally the verbさしあげる sashiageru must use three arguments which state dative に’ $n i$ ' which indicates the existence of a giver は ‘ $w a$ ', recipient に 'ni', and something given $を ' o$ '. Semantically and pragmatic use of diction and politeness in Japanese that the sashiageru verb has a lexical meaning only to give both goods and services from subordinates to superiors.

C. The 授ける sazukeru verb is a transitive verb that shows the meaning of giving from higher status to lower status. It has a lexical meaning bestowed, teach, offered. The use of these three verbs in grammatical meaning will be adjusted to the context of the sentence. In Indonesian it can be interpreted as offering. In the Big Indonesian Dictionary (https://kbbi.kemendikbud.go.id/kosakata) presents: /meng.a.nu.ge.rah.kan/ V presents; give as offerings. This is consistent with the data sentence (7-9). Structurally the verb 授ける sazukeru must use three arguments which state dative に ' $n i$ ' which indicates the existence of a giver は ‘ $w a$ ', recipient に ' $n i$ ', and something given を ' $o$ '. Semantically and pragmatic use of diction and politeness in Japanese that the verb meaning 授ける sazukeru 'presents' to make it easier for students to understand the use of the verb 授ける sazukeru 'offer' according to the context of the sentence. 


\section{REFERENCES}

Alwasilah, AC. 2010. Filsafat Bahasa dan Pendidikan, Bandung: Remaja Rosdakarya

Aryani, MRD. 2016. "Verba Berkasus Datif Bahasa Jepang”. Bandung: Universitas Telkom

Aryani, MRD. 2019. Pelbagai Aspek Sintaksis Bahasa Jepang. Yogyakarta: Kanisius

Bresnan, J. 2001. Lexical Functional Syntax. Oxford: Blackwell Publishers.

Butt, M. 2006. Theory of Case. Cambridge: Cambridge University Press

Chaer, A. 2010. Kesantunan Berbahasa. Jakarta: Rineka Cipta

Chaer, A. 2009. Pengantar Semantik Bahasa Indonesia. Jakarta: Rineka Cipta

Departemen Pendidikan Indonesia. 2008. Kamus Besar Bahasa Indonesia. Jakarta: Balai Pustaka

Givon, T. 2001. Syntax An Introduction. Vol I. Amsterdam: John Benjamins Publishing Company.

Givon, T. 2001. Syntax An Introduction. Vol II. Amsterdam: John Benjamins Publishing Company.

Katamba, F. 1993. Modern Linguistics: Morphology. London: The Macmillan Press

Leech, G. 1989. The Principles of Pragmatics. London and New York: Longman

Leech, G. 1993. Prinsip-Prinsip Pragmatik. Jakarta. Universitas Indonesia Press

Mislikhlah, St. 2014. “ Kesantunan Berbahasa”. Ar-Raniry: Internasional Journal of Islamic Studies Vol. 1. No. 2, hlm. 285-296. Jawa Timur: Sekolah Tinggi Agama Islam Negeri

Miyagawa, S \& Tsujioka, T. 2004. 'Argument Structure and Ditransitive Verbs in Japanese dalam Journal of East Asian Linguistics 13, Nedtherlans

Mizutani \& Mizutani. 1987. Politeness in Japanese. Toukyou: Japan

Nitta, Yoshio. 1991. Nihongo Bunрои Kenkyuи Josetsu. Toukyou-Japan: Kuroshio Shuppan

Pateda, 2001. Pengantar Semantik. Jakarta: Rineka Cipta

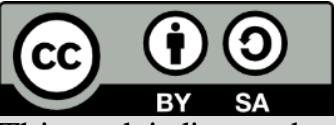


Rahardi, K. 2005. Pragmatik: Kesantunan Imperatif Bahasa Imperatif Bahasa Indonesia. Jakarta: Erlangga

Rahardi, K. 2009. Sosiopragmatik. Jakarta: Erlangga

Sudaryanto. 1983. Predikat-Objek dalam Bahasa Indonesia, Keselarasan Pola Urutan. Jakarta: Djambatan

Sudaryanto. 2015. Metode dan Aneka Teknik Analisis Bahasa. Yogyakarta: Duta Wacana Universitas Press

Sugai, K. 2000. 'Kakujoshi ni no Imi Tokusetsu ni Kansuru Oboegaki' dalam Hyougo Kyouikudaigaku Kenkyuu Kiyou Vol. 20

Shibatani, M. 2012.Grammatical Relations and Surface Cases. USA: Linguistic Society of America http://www.jstor.org/page/info/about/policies/terms.jsp

Sudaryanto. 1986. Predikat-Objek dalam Bahasa Indonesia, Keselarasan Pola Urutan. Jakarta: Djambatan

Sudaryanto. 2015. Metode dan Aneka Teknik Analisis Bahasa. Yogyakarta: Duta Wacana Universitas Press

Takahashi, T. 2003. Dooshi. Tokyo: Hitsuji Shoten.

Tsujimura, N. 1996. An Introduction to Japanese Linguistics. United Kingdom: Blackwell Publishing

Tsujimura, N. 2004. The Handbook of Japanese Linguistics. London: Blackwell

Verhaar, JWM. 1996. Asas- Asas Linguistik Umum. Yogyakarta: Gadjah Mada University

Wijana, DP. 1996. Dasar-dasar Pragmatik. Yogyakarta: Andi Yogyakarta

Zamzani, dkk. 2010. Pengembangan Alat Ukur Kesantunan Bahasa Indonesia dalam Interaksi Sosial Bersemuka dan Non Bersemuka. Laporan Penelitian Hibah Bersaing (Tahun Kedua). Yogyakarta: Universitas Negeri Yogyakarta

https://dictionary.goo.ne.jp/jn/131081/meaning/m0u/\%E4\%BE\%9B\%E3\%81\%88\%E3\%82\%8B/ https://kbbi.kemendikbud.go.id/kosakata 